\title{
On the value of human life
}

\author{
Emil Višňovský
}

\begin{abstract}
The author reflects on the issue of the value of human life in the contexts of current "posthuman" era. There is a host of evidence that the value of human for human beings themselves has been radically reduced or ignored, or replaced by other non-human values, and even neglected. The axiological crisis of humanity, as envisioned by Nietzsche, has become the existential and moral crisis of humanity today. No matter how contemporary technological culture challenges the traditional values, the ancient questions of "how to live?", "what makes us happy?", and "what makes life significant?" are still here with us and provide even greater challenges to every individual. The author points to pluralist ways of how to deal with these questions including the "stoic pragmatism" among them.
\end{abstract}

Keywords: human life, value, Konrad Liessmann, Bernard Stiegler, learning to live, stoic pragmatism

1

Let me begin trivially: "The most valuable thing we have is our life". Though it is vulnerable and fragile, unique and limited by its possibilities; nonetheless, it is the only one and ultimate. One does not have to be a philosopher to know that. And in case one is not a philosopher, one does not care about one's life, or the lives of others, "theoretically" because one just wants to live and "enjoy" one's life as fully as possible. One knows, or at least feels, that one has a natural "will to live" in the sense of Schopenhauer or Nietzsche, or Bergson's metaphysical élan vital or Teilhard's cosmic "will to live" for that matter; the power which is not only analogous to animal instincts of self-preservation, but which even transcends it considerably. And if one is lucky enough to succeed, the questions such as "How to live?" and "How ought one live?" may be put aside. Generally, one lives the way one is used to living and has learned to live when brought up within the family or by our surrounding environment (schooling included).

In spite of this, interest in the lives of others, often even strangers is what every art is based on and what "feeds" almost all media programmes: "celebrity" rumors; news of all kinds of human tragedies; the intense following of the fates of soap opera stars - these all attract us irresistibly and can "prove" that Alexander Pope was right as he wrote that "The proper study of mankind is man" (Pope, 2006, p. 281). Thus, interest in how people live - again, mostly the lives of others, how they thrive (or not), belongs to our spontaneity either because we want to learn from the lives of others, or we want to "judge" them, or we care about them because of them or because of ourselves. However, many times it is because we try to cover the escape from our own life via our interest - or even "worry" - in the lives of others...

By any means, life is not only the most valuable thing we have, but the most interesting, attractive, exciting thing no matter if in the form of comedy, or tragedy. Understanding and presentation of human fortunes and their troubles is an inherent substance of all areas of humanities, which nowadays suffer unprecedented traumas. "Depletion of the sense" that philosophers wrote about in the last century is a poor expression. Contemporary humans have begun a journey towards "post-humanism", eventually "trans-humanism", which considers technology as a determining tool for solving all problems of (human) life. The question what life means for a human (and what it means to be a human - moreover an "alive human"), is almost 
uninteresting because, due to biotechnologies, we are able to master and transfer the phenomena of life itself in a way that we seem to be soon capable of deciding about its quality, length, form and character. Life as a phenomenon, including human life, is not the most valuable thing anymore, because it is becoming the subject of almost ordinary manipulation within the visions of trans-humanists insomuch that our common sense, enhanced by traditional and modern forms of humanism, loses its capacity to absorb that at all.

Thus the question of the value of human life invokes serious concerns today. Our ability to manipulate the structure of living material at nano-level does not necessarily show that we are aware of this value. In fact, the contrary seems to be the case. We are faced with the question what a living human means to another living human on an everyday basis not just because of mass communication technologies due to which we recede from other living humans with whom we sit in the same room (or even share the same bed with), whereas, on the other hand, we get closer to other living humans on the other side of the world via our "online" connections. The same question occurs again more radically when we face the news of terrorist attacks. What is the concept of human life for a terrorist who blows himself up with the primary intention of killing? What is the concept of human life for a thug who, in cold blood, lets himself be recorded while cutting the throat of someone else? Or of the person who deliberately planned yesterday and rashly performed his "race to death" into a crowd today? We can paraphrase Bruno Latour along with Rosi Braidotti: "we have never been humane" at least not as far as the Western world is concerned. Humanism in terms of "universal humanness" was once our ideal, but has never been accomplished; on the contrary, crimes "against humanity" have been committed in the name of it as well as still are being committed on in the name of explicitely anti-humane doctrines. Human history so far has been enacted in a way that certain groups of people have lived at the expense of other groups (and what has mattered from the point of view of an individual has solely been his/her group membership). There has been no "universally unified humanity" and neither, it seems, is there any historical path leading to it. The line between the humane and the antihumane has never been clear enough, and has become even vaguer in our time, along with other frontiers. This "posthuman situation" of contemporary humanity poses the question: what have we made of ourselves and what are we still able to make?

\section{2}

The Austrian philosopher Konrad Paul Liessmann poses similar, equally urgent, questions, but, at the same time with a dignified levity. His Nietzschean views oppose every herd behavior of the time, whether talking about the field of education where the economic doctrine of "knowledge society" turns into "the theory and practice of miseducation" (Liessmann, 2006); or the field of politics where "the awareness of boundaries and differences" is losing itself, because "the spirit of the time" directs one to remove or cross borders (Liessmann, 2012); and finally even the field of daily life, which without critical philosophical reflection declines to the level of "the most deadly drug in the world"- fake, if not worse (Liessmann, 2010b). What about the value of a human? Primarily reduced to "human capital" as a main source of economic development, instrumentally measured and financially calculated together with other goods on the market regardless of what it should really consist and what can hardly be financially expressed - in human dignity (Liessmann, 2010a). It is crucial what position philosophy should hold towards the contemporary "post-human" world: should it assent to it, or be radical in terms of discovering the "roots" of it? What should contemporary philosophy be like in order to speak to modern humans and help them solve the question of "how ought we live?" (and, thus, in a way fulfill its ancient mission)? 
According to Liessmann (2000), it could be Nietzsche's philosophy as "a mirror of culture", revealing that behind the noble (ancient and even enlightened, Platonic or even Kantian) ideals of truth, beauty and goodness, their anti-poles, lies, ugliness and evil, remain hidden; forbidden and forbidding, suppressed and suppressing -. Science, art and morality as our most significant cultural constructions built just on one pole, on "a pure truth, beauty and goodness", are simply illusions which need to be exposed as their own anti-poles: truth as a type of error; beauty as our creation and goodness as a tool of the will to power, and altogether as expressions of the will to life (Nietzsche, 1968). Nietzsche's "philosophy of the will" moved primarily within the triangle between the will to life, will to knowledge and will to power. The will to life is the goal, however its effective tool is not the will to knowledge, but the will to power; the latter makes a decision whether and how to use or not to use the former within the interest of life itself. If knowledge is supported by power, it can serve life; if not, it's just an empty word, flatus vocis. To build life just on knowledge itself, without any power, is an illusion, because the key knowledge we need for life is knowledge of the relationship of life and power. Nietzsche went on by saying (1968, pp. 266-267): "Knowledge works as a tool of power. Hence it is clear that it increases with every increase of power... In other words: the measure of the desire for knowledge depends upon the measure to which the will to power grows in a species: a species grasps a certain amount of reality in order to become master of it, in order to press it into service". There are plenty of other opinions of this key triad - life, knowledge and power - and Nietzsche's "philosophy by hammer" would be best replaced by "philosophy by heart". However, the times when we were delighted by the illusion of our own "pure humanity" are gone. Hence we need, according to Liessmann (2000), even "the theory of untruth", "the aesthetics of ugliness" and "the ethics of evil" for contemporary philosophy. How can we gain our own value in our own eyes if we don't look at the dark side of our human face?

3

To look at ourselves in different ways is possible and probably even necessary. One such philosophical way is presented by the French philosopher Bernard Stiegler (2013) in his book What Makes a Life worthy subtitled "On Pharmacology". The term pharmakon is taken from Derrida's reading of Plato's Phaedrus (Derrida, 1981, pp. 63-171). Plato (1997, 230d-e) writes about "a tool" with dazing effects which may be used sometimes as a medicine, sometimes as poison. For Stiegler, it means that a pharmakon is everything that is "good and evil at the same time" (Stiegler, 2013, p. 10) and has positive as well as negative effects. In other words, the source of our greatest happiness is also, potentially, the source of our greatest unhappiness (and apparently it also holds vice versa).

Stiegler, in the introduction to his book, gives us (referring to Donald Winnicott) the example of a mother's care of her child as an example of what she teaches her child regarding the value of life to be lived. Thanks to this care, the child "feels the life", feels the contact with the mother and as much as it feels it, it grows up with the feeling of the value of life. And on the contrary (Winnicott also presents in it his works), the loss of "the feeling of life" and contact with mother as a consequence of relaxation or even loss of care, can become the beginning of a destructive process in which the awareness of the value of life (our own and others) is disrupted. The child is not capable of taking care of itself, therefore only the care of the mother (or her substitution in case of adoption) or of other closely related persons, gives it the feeling of the value of life. Stiegler goes on to generalize: the care, which as an ontological entity, does not exist but is made as a relationship between entities, is a pharmakon because its presence, or absence, even its form and quality, has, all in all, positive as well as negative effects. If, for instance, the care is a 
condition for human beings to "not to behave as non-human beings", the focus on the pharmakon is the key for the value of our life (Stiegler, 2013, pp. 4-5). It is the same in the case of other key factors of our life: thinking, creativity, economics, capital, work, media and mostly technology, because in the current global situation of humanity we can observe a tendency towards the dominance of the destructive sides of these pharmakons in the form of intellectual and economic crises, political and marketing manipulation, consumerism, stupidity and proletarisation of spirit, social pathology, etc. A destructive side of contemporary anthropogenesis as techno-genesis of humanity consists of the destruction of human desires which lose their contact with acknowledgement of the value of life. Therapy, according to Stiegler (2013), is "the invention of a new way of life" based on a "new way of caring about the world" which consists even in the value change of economics in terms of the original meaning as "a care" (oikos-nomos - the rules of the care of household). Techniques and technology as pharmakons can potentially improve, not only devastate life, however, these also require a value change. Stiegler summarizes his analysis with a call for "new criticism of life" and referring to Nietzsche's Will to Power in which Nietzsche requests a "new definition of the term 'life' as a will to power" (Nietzsche, 1968, p. 331). According to Stiegler, "stupidity is what opens the inhuman-being that [etrinhumain] we are". Therefore, "the only thing that, in its basest form, is worth being lived - in this life that must constantly be critiqued in order for it to be, in fact, worth living - is the struggle against stupidity" (Stiegler, 2013, p. 132).

\section{4}

Criticism can be a tool for life changes, but our will to life, our possibilities to live are always framed by culture. We can find "life patterns" in culture which exceed our individual being and effort. We all move within these patterns and adapt to them differently; we learn them consciously, but also take them over unconsciously; and everybody applies them according to their possibilities and capabilities, but just a few can exceed or change them. They are transpersonal, trans-individual patterns, which work in the long term and create something like "the character of human life". This shows that "this is the way we live here", "this is the way we have lived here for ages" and "this is the way everybody lives". It means that everyday ways of thinking, acting and behaving are reproduced in order to "live at all" and thus to keep the continuity of life which was "weaved" for years, decades, centuries. We can see a warranty in this continuity that life will go on further and will stay stable. In spite of all idiosyncrasies and individual creativity when self-creating our lives, the matter of how we live and why we live this way is not only a matter of our will or self-creation, because we take patterns, models or frames for our life from the culture of our community and our era. No matter how creative an individual is, s/he always "weaves" his/her way of life only from the material which an available culture offers, although, based on this, it may go different ways. However, the will to diversify from cultural patterns means to go "upstream"; to encounter misunderstandings; to face criticism from the conservative side; to risk isolation or emigration (inner or outer).

The character of current life - how people generally live - is described by intellectuals, artists, humanists and social scientists in different ways. They strive to catch the cultural frames or relevant features of the time, which enable us to understand how people live and why in this way and not the other; thus they indirectly show what ought to be changed, if people would like to live another way. An individual can - actually has to - manage his/her life in the best possible way; however it's obvious that "system parameters" are set for them by culture or social order. In this sense, a change in the way of human life is a system change, referring to the whole historical era or socio-cultural paradigm. 
From the point of view of contemporary man, we can still talk about modernity - about the paradigm of modern life whose key characteristics have been identified by diagnosticians and critics of modern culture such as Marx and Nietzsche, Dewey and Weber, Simmel and Freud, Marcuse and Fromm, Foucault and Deleuze and many others. Alienation, value crisis, the issue of the public, regimentation of life through rationalized orders, conformism, aggression, narcissism, discipline and control through norms, etc. - these all are just few of the signs determining the life of contemporary humans (in the West); these all are here to stay regardless the phase, no matter so called "post-modernity" or "late modernity". This late phase even emphasized some of these signs of modern life and added some more in the context of new events such as globalization or technologization of culture at the same time. Summa summarum: if anybody uncritically has thought that modern life with its conveniences creates a socio-cultural frame for human happiness automatically, generally still considered as the apex or the sense of life even in this form, they could easily go wrong (Bauman, 2008). It is not just about suicides, which were described by Masaryk and Durkheim in the $19^{\text {th }}$ century; about social or military conflicts and their consequences in the $20^{\text {th }}$ century, which influenced Adorno and Horkheimer; neither only about the forms of social pathologies in the form of social non-recognition, which have recently been analyzed by Honneth and Fraser, nor about much worse forms of social destructions such as corruption or terrorism. Cultural differences of capitalism, psychological consequences of the consumer "society of prosperity" or moral consequences of "the achieving society" have their implications for the life of modern man.

The complexity of the life situation of modern humans is characterized mainly by what Bauman calls "liquidity", i.e. plurality, openness, uncertainty, loss of reliability and blurring of all life patterns available before to modern living. Such living is "liquid", unstable, and one can, even has to, change one's life positions and styles according to situations which are changing in an unusually dynamic way. This kind of life is apparently brighter and more interesting, but also more demanding at the same time, and the question is whether and which "school" can teach us to live it. Bauman (2005) points to the fact that the "liquid life" is primarily characterized not only by its fast pace and the race for opportunities, but also by great worries arising from delays, depression arising from loss and the trauma of wasted investments. The art of living such a life is to learn to handle such losses as soon as possible, not to grieve over them so much, because every end means a new beginning, and every beginning will one day become an end. Therefore every loss can be a new gain, not just the other way round. Let's call it "flexibility" as one of the important competences which we need for such "a liquid life". It is the competence to forget, relieve, reset and supply everything greater than human living within a liquid modernity, but brought up in the "old school" way, could imagine. What was useful for life back then is seriously doubted today even disabled. Referring to the experience and extrapolation from the past to the future is too risky and misleading (Bauman, 2005, p. 1).

Individualization belongs to modern life; it includes responsibility for one's own life and its forms. It obviously holds true for modern human more than for every pre- or non-modern human. To become "the master of one's own life" and "to hold one's life in one's own hands" is one of the most significant aspects of the modern "turn to the subject", as Charles Taylor (1989) put it. Hence, the role of forming a deliberate attitude to life - in particular to one's own life - and to answer the question of "what to do with it?" is a practical life task of the modern subject. Life patterns work even here. In accordance with them, the approach of a modern human to life may be characterized at least by a well-known old term: instrumentalism. It means instrumentalization even in the understanding of life. Modern humans do not want just to live and spend their lives they want to benefit from it, achieve and create something; best of all to create something 
significant, if not directly a work of art. Simply, it's not enough for modern humans just to live their lives, but they need to make, shape and transform them actively. Our own life is becoming the object of our effort to give it value. To enjoy life is not enough, we need to make it fruitful; it should bring us the joy of the fruits it gives. This means that we do not treat our life as "a gift", but as a role or a problem; thus, through our life, we want to become someone. Our life is not an end for us, but a means; we cannot live it just for the sake of itself, but just for the sake of something else. We do not think of life itself, but of other things. We do not care about life in the same way as we care about anything else. We do not want to waste our life; hence, we work hard (or just speculate). We are ready to "give up our life" for something to give it value.

\section{5}

Thus, how ought we live? How to spend our life in order not to feel vanity or sorrow over what have we done? How to spend it meaningfully and worthily - and even non-instrumentally? How to fill the content and time of our life to be satisfied with that which "we have lived well"? What gives life worth? Why is a human life worthy? And what (or which) life is not worth living?

There are as many lives as there are values, which fill in these lives, and there are as many values which these lives possess. We need to admit that different things make the lives of different people worthwhile, even though not all of them equally to everybody. Furthermore, we need to realize that there is no absolute consensus, neither of authority within the question of values nor of evaluation; therefore, we need to respect the answers to these questions as subjective, or inter-subjective. Of course, cultural patterns and norms are present here, working as a social authority towards which all values and evaluations in particular contexts are specified; for instance, one of the best-known answers to the question, "what kind of life is not worth living?" Let us call it the enlightened answer; it had already been given by Socrates: life with no knowledge or understanding is not worth living, "for the unexamined life is not worth living for men" (Plato 1997, 38a). Socrates apparently over-reacted, as Robert Nozick (1989, p. 15) reproached him, because we cannot generalize it as a norm; it can hold true, at most, for scholars and philosophers, but in spite of this, such an "intellectual" norm, although not universal, has worked and is still working. However, we can also mention other aspects - ethical or political according to which not all human lives are equally worthy, which is getting closer to the function of social authority. Only a few would agree with the statement, that "for instance, Lenin, Hitler or Stalin or Mao Zedong and Pol Pot deserve the same respect as each of the tens of thousands of their victims in accordance with "the principle of the same value", that "every human being and every human life ideally ought to be equally valued", only "because it is about human beings as human beings" (Flew, 1990). Thus, there is a difference between human beings as well as between human lives. Some of them can be examples of spoiled or miserable lives, others of the best and most valuable lives which a human is capable of (There are a lot of "bright" examples of it within history beginning with Socrates through Jesus Christ or Albert Einstein up to Mother Theresa, if we can mention only a few of those generally accepted.)

However, philosophers, also ask the question of the value of life in itself when they put the question of whether "it is worth living?" It is a different question to this one: "what makes life worthy?" The first one reflects existential situations where somebody can make a decision between voluntarily death and continuation of life in an unbearable condition, and ask: "is it worth living in this way at all?" The second one reflects all other situations when the question of the value of life itself is not asked, or is definitely answered in a positive way.

Leaving theological conceptions aside, according to which the whole life - already at its beginning - is sacred, and thus a human is not allowed to take it away, therefore neither to ask 
questions about its "worth". Let us look at the philosophical conception asking it. It was William James (1896) who pointed out that the reasons for optimism in, and joy of, life exist, but as well as reasons for pessimism and sorrow in life, as it is "normal" that none of them last forever, but all are changing as the moods of a human are changing during a life, except for what we know today as a "bipolar mental disorder". James speaks here more as psychologist and a physician than a philosopher when he talks about mental health and intellectual integrity as conditions prohibiting the asking of this question. Contrary evidence for him is, however, suicide, which is sourced in an intellectual pessimism of "miserable images of life" as the consequence of worldview problems and "abstruse thinking", unable to achieve peace and balance of mind. Such problems are, for instance, conflicts between nature and spirit or the existence of evil. Inability to confront them intellectually leads to "philosophical melancholy", which can quite "rationally" come to the idea of suicide as a resignation from them. Philosophical minds are loaded with melancholy, depression, desperation, vanity, severe moods since they need to bear their intellectual burden, which can be their reason for pessimism. However, James shows that there is no fatality in this, because such problems can, on the contrary, stimulate us to an active search, which is a position supporting life. Along with Stiegler, we can say that philosophy (and theology as well) is a pharmakon, which potentially is a medicine and a poison at the same time. What will come out as dominant is up to us; we make that decision ourselves, even according to W. James. However, we need the courage to perform it and the faith to prove that life is worth that. Our faith does not guarantee anything to us, it just gives us the chance to "say yes to life" (James, 1896, pp. 60-63). Faith in life is an intellectual power, which makes life worthy, helps to create it actively and to challenge absurdity, negativity and pessimism.

If we cannot be blamed for our life (our birth to life) as individuals, what else ought we do than live? What other better possibilities, alternatives do we have? If somebody reaches the stage that it is a better alternative for him/her "not to live" and to end his/her life, it is a hard decision, but it is a part of his/her life. Because, as Epicurus said, as long as we exist, death is not here, and when it does come, we no longer exist. There is no better alternative for the French philosopher André Comte-Sponville, as he writes about the "will to live" (in other, personal, nonmetaphysical and non-theological dimensions than Teilhard de Chardin discussed). He writes: "Life is good in spite of everything; it's good because of itself; why speculate about it... To exist is good, there is nothing better than that; because to exist is everything and not to exist is nothing... We are not sentenced to life at all; we live lustfully. To live means the will to live. Every single life is an enjoyable song" (Comte-Sponville, 1999, pp. 49-50). There is no cheap optimism inside of it. The philosopher is aware of the seriousness of suicide and the situations which lead towards it; it's rather "the escape from unhappiness", than "refusing life" (ComteSponville, 1999, p. 51). He does not refuse Sisyphean absurdities, neither the tragedy of life nor does he let himself become fascinated by delights. Life needs "to be accepted and loved" as it is, with all its pros and cons, because the one who "loves just happiness, does not love life, and suppresses himself from being happy..." (Comte-Sponville, 1999, p. 62).

\section{6}

What does make us happy? What do we need to enjoy life? Clearly, a lot of particular beings, things, events, and processes. W. James thought about it in his article "What makes a life significant". He assumes that the significance of life is personal for everyone and if a human cannot see it, it does not mean it does not exist for others. But we should strive to overcome our 
"blindness" towards others, learn to respect and tolerate their various ways of life. James overcomes well-known philosophical intellectualism, according to which it is really hard to accept the value and significance of other life activity than philosophy itself (notably in the sense of Plato and Aristotle, who considered a "contemplative" way of life as the best one). Humans can find their happiness and its meaning even in regular everyday activities, in manual and physical activities and their lives do not stop being worth living. We need other virtues important for our worthy life such as courage, patience and kindness, moral ideals helping us to overcome difficult life conditions. The rate of happiness is the rate of balance between everything that humans need for their lives and what is available to them.

The contemporary American philosopher Owen Flanagan joins both questions into one: "Is life worth living and if yes, what makes it so?", even though he accepts that life can be worth living also for those who cannot say why; or for somebody there are worthy things in life, but they just lose their will to live. A more fundamental question is "What does it mean to live at all?" which is not sufficient to answer just by saying "not to be dead"; but at least we need "to control our life", make decisions regarding it. What makes life worthy, cannot come only from the fact of "being alive" and reduced to this simple answer. Neither is happiness a factor, which is worthy of life, because somebody can find happiness even in unworthy things (Flanagan, 1996, p. 4). A necessary, although not sufficient, condition of worthy life is, according to Flanagan, "selfrealization", i.e. realization of one's self (Flanagan, 1996, p. 5), which is anything else than "life by myself" in accordance with myself meaning "to live my own life", as Steve Jobs said during his promotional lecture at Stanford University on July $12^{\text {th }} 2005$ : "Your time is limited, so don't waste it living someone else's life. Don't be trapped by dogma - which is living with the results of other people's thinking. Don't let the noise of others' opinions drown out your own inner voice. And most important, have the courage to follow your heart and intuition. They somehow already know what you truly want to become. Everything else is secondary" (Jobs, 2005). To live one's life according to one's will does not mean to live it just for oneself and against others. It means to transcend one's own 'I' into the world and lives of others (Flanagan, 1996, p. 10).

According to M. Csikszentmihalyi, we are programmed in a way so that others would be the most important thing in the world for us, and therefore our happiness is largely dependent on how we handle our relationships with them. For the whole life, we look for the one or the ones with whom we feel good, although we don't need to know what it means to feel the goodness of cobeing with them. If the source of our greatest happiness is (potentially) the source of our greatest unhappiness, afterwards, living together with somebody else is one of the summits of happiness, as long as a phobia of being refused by somebody else, not being understood by them or being left on our own is one of the greatest unhappinesses. "People are the most flexible, the most changeable aspect of the environment we have to deal with" (Csikszentmihalyi, 1990, p. 166). On the other hand, we care who we are - if we have to be with somebody, who is not convenient for us, we opt for an escape, for some sort of seclusion. This can be worthy as well. "Yet how one copes with solitude makes all the difference. If being alone is seen as a chance to accomplish goals that cannot be reached in the company of others, then instead of feeling lonely, a person will enjoy solitude and might be able to learn new skills in the process. On the other hand, if solitude is seen as a condition to be avoided at all costs instead of as a challenge, the person will panic and resort to distractions that cannot lead to higher levels of complexity" (Csikszentmihalyi, 1990, p. 175). 
Let me conclude in the same vein as I began: "Everybody is the creator of his/her own happiness." But how is it possible when we do not live our lives in a vacuum, but in particular conditions, which transcend us and which we have not created, but rather just inherited? Here, our desires are met with our possibilities; our aims with the aims of others; our will to live with others' will to live. Hic Rhodus, hic satla! Right here, hic, we have to prove what powers we have and what we don't have under control, as Epictetus recommended - if we want to master the art of a good life. Considering the situation, conditions, circumstances and mainly other humans with their own ideas of life, this does not mean to give up on our own life "according to oneself". It does not mean to choose between "either me or you", nor "either everything or nothing". It rather means to challenge the route of creatively and patiently searching for the understanding of life and others regarding the achievement of some balance - if not harmony - between what we want and what others want. To prefer ones at the expense of others means a conflict, and since the handling of conflicts is a part of the art of life, the most optimal solution seems the "win/win" strategy for both (or all) sides. Thus, according to the life credo: "Live and Let Live!"

And what about philosophy? Does it "finally teach us how to live", as none other than Jacques Derrida (2005) had grieved for? We do not just live our life, but even think of it, and there is also a very close relationship between how we live and how we think of life: "Philosophy becomes marginalized only when it distances itself from the problems of life... There is no greater social need than guidance in the affairs of life... Since philosophers have abandoned their responsibility in this sphere, the public has abandoned philosophers... But philosophy for its own sake is, in the end, of value only because it makes philosophy for life possible" (Lachs, 2003, pp. 11, 14).

The same philosopher came up with the conception of the creative connection of stoicism and pragmatism, thus "stoic pragmatism" (Lachs, 2012), which can be considered as a prominent example of the ethical conception of the pragmatist art of living. Stoic pragmatists "are committed to making life better until their powers are overwhelmed. When circumstances render aggressive affirmation no longer possible, however, they surrender to the inevitable gracefully and without complaint. As pragmatists, they insist on the centrality of intelligence in the conduct of life, but they extend the reach of good sense to the acknowledgement of failure or futility" (Lachs, 2012, p. 1).

Stoic pragmatism shows how stoicism and pragmatism can mutually benefit and complete each other by balancing their opinions on a conflict and the humbleness, power and definitiveness of human life; thus to both poles of life, which present pleasure versus sorrow; joy versus suffering; enthusiasm versus disappointment; beauty of life versus its absurdity, etc. A real life most often balances between both of these poles - between a life of happiness and of unhappiness. The pragmatist art of living tends to both of these tendencies as well: to the fulfillment of the human's lot by luck and to the wisdom of how to bear real unhappiness in a dignified way.

What could this mean "to know" regarding the issues of life? Who of us can say that they "know how to live", if none other than Derrida admitted at the very end of his life journey precisely this: "I never learned-to-live. In fact not at all! ..." (Derrida, 2007, p. 24)? Does it mean to know what to do with our life, what to dedicate it to? Does it mean, in spite of everything, to know how to face the challenges, not only negative, but even positive ones, in order not to lose the will to live? Not to be disgusted? Not to lose all love for life? Keep the will to live, desire to live, reason to live and hope to live by all means? Be enlightened every single day...

Everybody has their own light, somebody else is the light in himself/herself; it is very inspiring when at least two people can find the understanding in what this light brings them - if 
they are a light for each other. And it does not stand just for love; every mutual respect, empathy, intellectual understanding, friendship means that light - in a word, every way of appreciation of the value of a living human by and for another living human.

To know how to live means to know how to combine the will to live with the respect for it. This is the right opposite to what is happening in the human world at present: the will to live (our own life) without any respect for (the) life (of others). This is the world we have been creating for as long as we can remember. In what name do we create it? In the name of life? What kind of life and who is it for?

\section{Acknowledgement}

This publication is the result of the project implementation: Comenius University Science Park $2^{\text {nd }}$ phase supported by the Research \& Innovation Operational Programme funded by the European Regional Development Fund.

Emil Višňovský is Professor at the Department of Philosophy and History of Philosophy, Faculty of Arts, Comenius University in Bratislava. Currently he teaches courses in the philosophy of artificial intelligence and neurophilosophy. His scholarship is Anglo-American philosophy and he is the author of several books and numerous articles published in journals and volumes in Slovakia and abroad, e. g. Prolegomena to Pragmatist Conception of the Good Life. In: K. P. Skowronski (ed.): Practicing Philosophy as Experiencing Life: Essays on American Pragmatism. Leiden \& Boston: Brill/Rodopi, 2015.

\section{Corresponding author:}

Emil Višňovský, Department of Philosophy and History of Philosophy, Faculty of Arts, Comenius University, Gondova 2, P.O.BOX 32, Bratislava (Slovakia)

Email: emil.visnovsky@uniba.sk

\section{References}

BAUMAN, Z. (2005): Liquid Life. Cambridge: Polity.

BAUMAN, Z. (2008): The Art of Life. Cambridge: Polity.

COMTE-SPONVILLE, A. (1999): Improvizácie [Improvisations]. Bratislava: R. Farbula.

CSIKSZENTMIHALYI, M. (1990): Flow: The Psychology of Optimal Experience. New York: HarperCollins.

DERRIDA, J. (1981): Disseminations. Chicago \& London: University of Chicago Press.

DERRIDA, J. (2007): Learning to Live Finally. Houndmills: Macmillan Palgrave.

FLANAGAN, O. (1996): Self-Expressions. Oxford: Oxford University Press.

FLEW, A. (1990): Equal Liberty versus Equal Value. Cogito [online]. [Retrieved August 18 2016]. Available at: http://www.libertarian.co.uk/lapubs/polin/polin063.pdf

JAMES, W. (1896): Is Life Worth Living? Philadelphia: S. Burns Weston.

JAMES, W. (1925): Talks to Teachers on Psychology: and to Students on some Life's Ideals. New York: Henry Holt and Company.

JOBS, S. (2005): You've got to find what you love, Jobs says. Stanford News, June 14 [online]. [Retrieved July 14 2016]. Available at: http://news.stanford.edu/2005/06/14/jobs-061505/

LACHS, J. (2003): A Community of Individuals. New York \& London: Routledge.

LACHS, J. (2012): Stoic Pragmatism. Bloomington \& Indianapolis: Indiana University Press. 
LIESSMANN, K. P. (2000): Philosophe des Verbotenen Wissens Friedrich Nietzsche und die schwarzen Setien des Denkens. Wien: Paul Zsolnay Verlag.

LIESSMANN, K. P. (2006): Theorie der Unbildung. Wien: Paul Zsolnay Verlag.

LIESSMANN, K. P. (2010a): Hodnota člověka. Filosoficko-politické eseje [Value of man: Philosophical-ethical essays]. Prague: Academia.

LIESSMANN, K. P. (2010b): Das Univerzum der Dinge. Zur Ästhetik der Altäglichen. Wien: Paul Zsolnay Verlag.

LIESSMANN, K. P. (2012): Lob der Grenze: Kritik der politischen Unterscheidungskraft. Wien:

Paul Zsolnay Verlag.

NIETZSCHE, F. (1968): The Will to Power. New York: Vintage Books.

NOZICK, R. (1989): The Examined Life. New York: A Touchstone Book.

PLATO (1997): Phaedrus, trans. by A. Nehamas \& P. Woodruff. Indianapolis: Hackett Publishing Company.

POPE, A. (2006): The Major Works. Oxford: Oxford University Press.

STIEGLER, B. (2013): What Makes Life worth Living. Cambridge: Polity.

TAYLOR, Ch. (1989): Sources of the Self. Harvard: Harvard University Press. 